\title{
PENGEMBANGAN PERANGKAT PEMBELAJARAN FISIKA MODEL INKUIRI TERBIMBING BERBANTUAN VIDEOSCRIBE PADA MATERI KALOR UNTUK MENINGKATKAN HASIL BELAJAR SISWA SMAN 1 KEDUNGWARU
}

\author{
Fitria Rahmawati'), Soegimin' ${ }^{2)}$, Soeparman Kardi ${ }^{3)}$ \\ ${ }^{1)}$ Mahasiswa Program Studi Pendidikan Sains, Program Pascasarjana Universitas Negeri Surabaya \\ ${ }^{2), 3)}$ Dosen Pascasarjana Prodi Pendidikan Sains Univesrtitas Negeri Surabaya \\ Email: fitriarahma.mpale@gmail.com
}

\begin{abstract}
The aim of this research is to develop physics learning material based on guided inquiry model completed video scribe at heat material to improve senior high school achievement. Development of Physics Learning Material is used Dick and Carey model, this research using one-group pretest-posttest design. Data were analyzed using descriptive analysis qualitatively and quantitatively. Validation results showed that learning material is feasible to be implemented, including: (a) lesson plan; (b) student worksheet; (c) student books; (d) evaluation instrument. The results of this research were analyzed and obtained: lesson plan was properly implemented, good student responses, all students interested in learning. Learning evaluation of knowledge, $\mathrm{N}$ gain include knowledge aspect and critical thinking skills, showed high improvement. Concluded that, physics learning materials developed is feasible to implemented and it can improve the student achievement..
\end{abstract}

Keyword: Physics Learning Materials, Guided Inquiry Model, Learning Achievement, Critical Thinking Skills

\begin{abstract}
Abstrak: Penelitian ini bertujuan mengembangkan perangkat pembelajaran fisika berbasis model inkuiri terbimbing berbantuan videoscribe yang layak untuk meningkatkan hasil belajar siswa SMA pada materi kalor. Pengembangan perangkat pembelajaran menggunakan model Dick and Carey, perangkat pembelajaran diujicobakan pada sekelompok subjek dengan rancangan one group pretest-posttest design. Data yang diperoleh dianalisis secara deskriptif kuantitatif dan kualitatif. Hasil validasi perangkat pembelajaran menunjukkan perangkat pembelajaran layak untuk diimplementasikan, meliputi: (a) RPP; (b) LKS; (c) Buku Ajar; (d) Media videoscribe; dan (e) Tes Hasil Belajar. RPP terlaksana dengan baik, dan siswa memberikan respon positif terhadap pembelajaran. $\mathrm{N}$-Gain pada aspek pengetahuan dan keterampilan berpikir kritis menunjukkan peningkatan dengan kategori tinggi. Kesimpulan dari penelitian ini yakni perangkat pembelajaran yang dikembangkan layak diimplementasikan dan dapat meningkatkan hasil belajar siswa.
\end{abstract}

Kata Kunci: Pembelajaran Fisika, Inkuiri Terbimbing, Hasil Belajar, Keterampilan Berpikir Kritis

\section{PENDAhUluan}

Tujuan pendidikan nasional diimplementasikan dalam kurikulum. Perkembangan Ilmu Pengetahuan dan Teknologi membuat perubahan dan perbaikan pada kurikulum untuk mempersiapkan sumber daya manusia yang tangguh dan memiliki daya saing.

Fisika bagian dari Ilmu Pengetahuan Alam (IPA) merupakan proses dan produk tentang pengkajian gejala alam. Fisika merupakan ilmu yang sistematis dan menyatu. Sistematis karena produk yang satu berkaitan dengan produk yang lain, dan menyatu karena produk satu dengan lainnya dapat saling menunjang (Sutarto dan Indrawati, 2010). Fisika tidak hanya berisi teoriteori atau rumus-rumus untuk dihafal tetapi fisika juga berisi banyak konsep yang harus dipahami secara mendalam (Bektiarso, 2000). Tujuan pembelajaran fisika di SMA adalah untuk membentuk sikap positif; memupuk sikap ilmiah; mengembangkan kemampuan bernalar dalam berpikir analisis; induktif; dan deduktif dengan menggunakan konsep dan prinsip fisika untuk menjelaskan berbagai peristiwa alam dan menyelesaikan masalah baik secara kualitatif maupun kuantitatif, serta mempunyai keterampilan mengembangkan ilmu pengetahuan dan teknologi (Kemendikbud, 2006). Hal ini mengindikasikan bahwa dalam memahami materi fisika memerlukan pemikiran dan penalaran agar dapat menyelesaikan masalah fisika. Penguasaan materi sains (fisika) diperlukan keterampilan berpikir dasar (Novak \& Gowin, 1985) dan juga keterampilan berpikir kompleks, termasuk berpikir kritis (Costa, 1985). Hasil wawancara terhadap guru mata pelajaran fisika menunjukan sebagian besar siswa kesulitan dalam memahami materi fisika, terutama materi yang membutuhkan analisis, 
memerlukan konsep berpikir tingkar tinggi. Keterampilan berpikir kritis siswa masih rendah. Siswa belum dilatihkan keterampilan berpikir kritis dalam menyelesaikan permasalah fisika. Pada hakikatnya pembelajaran fisika memerlukan keterampilan berpikir logis, kritis, dan reflektif. Dalam mengembangkan keterampilan berpikir kritis, seperti halnya mengembangkan keterampilan motorik, keduanya memerlukan latihan-latihan (Penner, 1995, dalam Kartimi, dan Liliasari, 2010).

Merujuk pada rendahnya keterampilan berpikir kritis siswa, maka dalam pembelajaran fisika perlu dilatih untuk mengembangkan keterampilan berpikir kritis. Ennis (1985) mendefinisikan berpikir kritis sebagai cara berpikir reflektif yang masuk akal atau berdasarkan penalaran yang difokuskan, untuk menentukan apa yang harus diyakini dan dilakukan. Berpikir kritis menggunakan dasar proses berpikir untuk menganalisis argumen dan memunculkan wawasan terhadap tiap-tiap makna dan pretasi, untuk mengembangkan pola penalaran yang kohesif dan logis, memahami asumsi dan bias yang mendasari tiap-tiap posisi, memberikan model presentasi yang dapat dipercaya, ringkas dan meyakinkan.

Glaser juga menyatakan bahwa berpikir kritis adalah suatu pengetahuan dari metode inkuiri atau penemuan. Pendapat Glasser yang terakhir mengenai berpikir kritis adalah keterampilan yang dapat diimplementasikan melalui metode inkuiri. Pendekatan inkuiri membantu siswa untuk mengembangkan kemampuan penyelidikan, membangun pemahaman dan pengetahuan ilmiah, lebih lanjut keterlibatan siswa dalam menyelidiki akan memberikan dasar yang kuat bagi siswa untuk mengembangkan pemahaman tentang karakteristik sains dan inkuiri. Tetapi, dalam perkembangannya, siswa yang belum terbiasa dalam belajar mandiri, memerlukan bimbingan guru dalam pembelajaran penemuan.

Pembelajaran inkuiri terbimbing memiliki beberapa keunggulan, menurut Kuhlthau dan Todd (2008), karakteristik inkuiri terbimbing yaitu siswa belajar aktif dan terefleksasi pada pengalaman, siswa menggunakan pengetahuan yang sebelumnya diketahui dalam pembelajaran, mendapatkan bimbingan dalam mengembangkan rangkaian berpikir selama proses pembelajaran, perkembangan kognitif siswa terjadi secara bertahap, melatihkan metakognitif, dan siswa belajar interkasi sosial dengan orang lain.

Pembelajaran dengan inkuiri terbimbing membuat siswa dapat membangun pengetahuan dengan apa yang telah mereka ketahui sebelumnya (Kuhlthau \& Todd, 2008). Ausubel mengembangkan teknik advance organizer untuk membantu siswa memperlajari materi baru dengan mengingat kembali informasi-informasi yang berkaitan. Menurut Alverman et al (1985, dalam
Nur, 2008) Advance organizer dapat meningkatkan pemahaman siswa, tetapi metode mengaktifkan kembali pengatahuan dulu dapat gagal jika pengetahuan sebelumnya lemah. Menjembatani hal tersebut, maka dalam pembelajaran inkuiri terbimbing dapat dibantu dengan media video scribe. Video scribe dapat mengilustrasikan konsep yang kompleks dalam pembelajaan, meningkatkan minat, dan motivasi siswa (Sparkol, 2014). Videoscribe merupakan sebuah software yang digunakan guru dan siswa membuat animasi berbentuk papan tulis untuk meningkatkan minat dan retensi dalam pembelajaran. Videoscribe dapat meningkatkan pembelajaran dengan mengkombinasikan audio dan visual. Menurut Mayer (2009) siswa lebih memahami konsep dalam pembelajaran dengan animasi. Penggunaan model inkuiri terbimbing berbantuan videoscribe ini diharapkan dapat meningkatkan keterampilan berpikir kritis siswa.

Hasil penelitian Thorir M, et al (2013) menyimpulkan bahwa implementasi pembelajaran metode penemuan terbimbing dapat meningkatkan keterampilan berpikir kritis. Rahmawati, et al (2013) menyimpulkan pembelajaran IPA fisika dengan metode 'guided discovery' dapat melatih keterampilan berpikir kritis serta mampu menuntaskan penguasaan konsep kognitif siswa. Windarti, et al (2014) menyimpulkan pembelajaran inkuiri terbimbing efektif untuk melatihkan kemampuan berpikir kritis siswa dan meningkatkan hasil belajar. Miri, et al (2007) menyimpulkan bahwa jika guru menggunakan strategi belajar dengan mengaplikasikan kemampuan berpikir tingkat tinggi, seperti menghubungkan dengan permasalahan otentik, membangun 'open-ended' dalam diskusi kelas, mendorong penemuan yang berorientasi pada eksperimen, hal ini dapat mengembangkan keterampilan berpikir kritis.

Penelitian Mayer (2009). Sparkol (2014) menyimpulkan bahwa penggunaan video scribe dapat meningkatkan retensi. Liliasari (2010) menyimpulkan bahwa pembelajaran inkuiri menggunakan tekonologi informasi dan komunikasi dapat mengkatifkan siswa, mendukung teori dan praktikum di laboratorium, memotivasi, dan meningkatkan penguasaan konsep siswa.

Berdasarkan penjelasan di atas dipilih model inkuiri terbimbing berbantuan videoscribe untuk meningkatkan keterampilan berpikir kritis yang merupakan bagian dari hasil belajar, pada siswa kelas X SMA Negeri 1 Kedungwaru, Tulungagung pada materi kalor. Peneliti ingin merancangkan dan melakukan penelitian berjudul "Pengembangan Perangkat Pembelajaran Fisika Model Inkuiri Terbimbing Berbantuan Video Scribe pada Materi Kalor untuk Meningkatkan Hasil Belajar Siswa SMAN 1 Kedungwaru”. 


\section{METODE PENELITIAN}

Jenis penelitian ini adalah penelitian pengembangan karena mengembangkan perangkat pembelajaran fisika model inkuiri terbimbing berbantuan video scribe pada materi kalor untuk meningkatkan hasil belajar. Perangkat pembelajaran yang dikembangkan meliputi: rencana pelaksanaan pembelajaran (RPP), buku ajar siswa (BAS), lembar kerja siswa (LKS), media video scribe, dan lembar penilaian. Penelitian pengembangan ini mengacu pada model pengembangan Dick and Carey yang dimodifikasi oleh peneliti sesuai dengan kebutuhan di lapangan. Subjek penelitian ini adalah perangkat pembelajaran yang telah dikembangkan dan diuji cobakan pada 120 siswa kelas X MIA di SMA Negeri 1 Kedungwaru, Tulungagung tahun pelajaran 2014/2015. Penelitian ini dilaksanakan pada 3 kali pertemuan semester genap tahun 2015

Prosedur penelitian pengembangan dilaksanakan menjadi dua tahap yaitu: tahap pengembangan dan tahap uji coba. Pengembangan perangkat pembelajaran model inkuiri terbimbing untuk meningkatkan hasil belajar siswa pada penelitian ini menggunakan model pengembangan Dick and Carey. Berikut ini prosedur pengembangan perangkat pembelajaran dalam penelitian:

1. Identifikasi tujuan umum pembelajaran

2. Melakukan analisis pembelajaran

3. Analisis siswa dan koneks

4. Menuliskan tujuan kinerja

5. Mengembangkan instrumen penilaian

6. Mengembangkan strategi pembelajaran

7. Mengembangkan dan memilih materi pembelajaran

8. Mendesain dan melaksanakan evaluasi formatif

9. Mendesain dan melaksanakan evaluasi sumatif

10. Desain awal perangkat pembelajaran (Draft I)

11. Validasi perangkat pembelajaran

12. Hasil validasi/Revisi II (Draft 2)

13. Uji coba I

14. Analisis hasil uji coba I

15. Revisi III:Drfat 3

16. Uji coba II

17. Analsisi hasil uji coba II

18. Revisi IV: Draft 4

19. Perangkat pembelajaran yang layak

Rancangan dalam penelitian ini menggunakan rancangan One-Group Pretest-Posttest Design dengan rancangan sebagai berikut:

\section{$\begin{array}{lll}\mathrm{O}_{1} & \mathrm{X} & \mathrm{O}_{2}\end{array}$}

Keterangan:

$\mathrm{O}_{1}$ : Uji awal (pre-test), untuk mengetahui penguasaan awal siswa terhadap pengetahuan tentang materi sebelum diberikan perlakuan.
$\mathrm{X}$ : Perlakuan, yaitu pelaksanaan pembelajaran menggunakan model inkuiri terbimbing berbantuan video scribe.
$\mathrm{O}_{2}$ : Uji akhir (post-test), untuk mengetahui penguasaan terhadap materi setelah proses pembelajaran

Variabel pada penelitian ini terdiri dari validitas perangkat pembelajaran, keterlaksanaan pembelajaran fisika menggunakan model inkuiri terbimbing, hasil belajar siswa, respon siswa terhadap pelaksanaan pembelajaran, hambatan yang muncul selama proses pembelajaran.

Teknik pengumpulan data pada penelitian ini meliputi: dokumentasi, observasi, tes, dan angket. Instrumen yang digunakan dalam penelitian ini terlebih dahulu divalidasi yang meliputi Rencana Pelaksanaan Pembelajaran (RPP), Validitas Buku Ajar Siswa (BAS), Lembar Kegiatan Siswa (LKS), penilaian hasil belajar.

Teknik analisis data yang dilakukan untuk rumusan masalah menggunakan analisis data deskriptif kuantitatif-kualitatif. Tujuan analisis ini adalah untuk mendiskripsikan peningkatan hasil belajar siswa setelah proses pembelajaran dengan menggunakan inkuiri terbimbing berbantuan video scribe pada materi kalor. Analisis ini meliputi validitas pengembangan perangkat dan implementasi perangkat pembelajaran

Analisis data perangkat pembelajaran dilakukan dengan deskriptif kuantitatif dan kualitatif yaitu dengan merata-rata skor hasil validasi setiap komponen. Hasil skor rata-rata dideskripsikan sebagai berikut

Tabel 1. Kategori validasi perangkat pembelajaran

\begin{tabular}{|c|c|l|}
\hline Interval Skor rata-rata & Kategori & \multicolumn{1}{|c|}{ Keterangan } \\
\hline $1,0 \leq S \mathrm{~V} \leq 1,59$ & Tidak Baik & $\begin{array}{l}\text { Belum dapat digunakan dan masih } \\
\text { memerlukan konsultasi }\end{array}$ \\
\hline $1,00 \leq \mathrm{SV} \leq 2,59$ & Kurang Baik & Dapat digunakan dengan banyak revisi \\
\hline $2,00 \leq \mathrm{SV} \leq 3,59$ & Baik & Dapat digunakan dengan sedikit revisi \\
\hline $3,00 \leq \mathrm{SV} \leq 4,00$ & Sangat Baik & Dapat digunakan tanpa revisi \\
\hline
\end{tabular}

Sumber: Ratumanan dan Laurens (2011)

Teknik yang digunakan untuk menganalisis data hasil pengamatan keterlaksanaan pembelajaran adalah deskriptif kualitatif. Penilaian dan pengamatan dilakukan setiap kali tatap muka oleh pengamat yang sudah dilatih sehingga dapat mengoperasikan lembar pengamatan secara benar. Teknik analisis data dihitung dengan persamaan berikut.

$$
P=\frac{\text { Jumlah aspek yang dilaksanakan }}{\text { Jumlah seluruh aspek yang diamati }} \times 100 \%
$$

(Arifin, 2009)

Tabel 2. Persentase keterlaksanaan pembelajaran menggunakan kriteria sebagai berikut:

\begin{tabular}{|l|l|}
\hline $0 \%-24 \%$ & $:$ tidak terlaksana \\
\hline $25 \%-49 \%$ & $:$ terlaksana kurang \\
\hline $50 \%-74 \%$ & $:$ terlaksana baik \\
\hline $75 \%-100 \%$ & $:$ terlaksana sangat baik \\
\hline
\end{tabular}


Tabel 3. Perbandingan rata-rata peniaian kedua pengamat, menggunakan kriteria:

\begin{tabular}{|l|l|}
\hline $1.00-1.49$ & $:$ Tidak baik \\
\hline $1.50-2.49$ & $:$ Kurang baik \\
\hline $2.50-3.49$ & : Cukup baik \\
\hline $3.50-4.00$ & : Baik \\
\hline
\end{tabular}

(Ratumanan \& Laurens, 2006)

\section{A. Mengukur Pengetahuan}

Hasil belajar dikatakan mencapai ketuntasan secara individu jika memenuhi Kriteria Ketuntasan Minimal (KKM) yang telah ditetapkan. KKM di tempat penelitian yaitu 75 atau 3,00 untuk kompetensi pengetahuan. Secara individual, ketuntasan siswa dapat dihitung dengan persamaan berikut.

ketuntasan individual $=\frac{\sum \text { indikator yang tercapai }}{\sum \text { indikator }} \times 100 \%$

Ketuntasan hasil belajar klasikal dihitung dengan persamaan berikut.

Ketuntasan klasikal $=\frac{\sum \text { siswa yang tuntas }}{\sum \text { siswa }} \times 100 \%$

Kriteria ketuntasan untuk masing-masing indikator atau tujuan pembelajaran adalah $75 \%$. Satu indikator atau tujuan pembelajaran dikatakan tuntas apabila persentase (P) siswa yang mencapai indikator tersebut $\geq 75 \%$. Perhitungan persentase ketuntasan indikator atau tujuan pembelajaran dapat dihitung menggunakan rumus berikut ini.

$$
P=\frac{\sum \text { siswa yang mencapai indikator }}{\sum \text { seluruh siswa }} \times 100 \%
$$

Data hasil pretest dan posttest siswa dianalisis menggunakan $N$-gain Score. $N$-gain menunjukkan peningkatan hasil belajar siswa sebelum dan sesudah perlakuan.

Keterangan:

$$
\langle g\rangle=\frac{S_{\text {post }}-S_{\text {pre }}}{S_{\text {max }}-S_{\text {pre }}}
$$

$\langle g\rangle \quad$ : Nilai gain

$S_{\text {post }}$ : Nilai posttest

$S_{\text {pre }}$ : Nilai pretest

$S_{\max }:$ Nilai maksimal

Kriteria skor $n$-gain diklasifikasikan pada tabel 3.

Tabel 4. Kriteria normalized gain

\begin{tabular}{|c|c|}
\hline Skor N-Gain & Kriteria Normalized Gain \\
\hline$N$-Gain $<0,3$ & Rendah \\
\hline $0,3 \leq N$-Gain $<0,7$ & Sedang \\
\hline$N$-Gain $\geq 0,7$ & Tinggi \\
\hline
\end{tabular}

\section{B. Mengukur Keterampilan}

(Hake, 1999)

Teknik yang digunakan untuk menganalisis data hasil belajar ketrampilan tersebut adalah deskriptif kualitatif. Pengamatan dilakukan setiap pembelajaran berlangsung oleh pengamat menggunakan lembar observasi keterampilan. Skor rata-rata yang diperoleh siswa tiap aspek keterampilan yang teramati dikonversi

pada skala $1-4$ dengan rumus pengolahan nilai sebagai berikut.

$$
\frac{\text { Jumlah skor }}{\text { Nilai maksimal }} \times 4=\text { skor akhir }
$$

\section{Mengukur Sikap}

Teknik yang digunakan untuk menganalisis data hasil belajar sikap adalah deskriptif kualitatif. Pengamatan dilakukan setiap pembelajaran berlangsung oleh pengamat menggunakan lembar observasi sikap. Penilaian didasarkan pada observasi dan kreteria rentangan yang terlampir pada Permendikbud No.104 tahun 2014.

\section{Mengukur Respon Siswa}

Data respon siswa dianalisis secara deskriptif kualitatif. Teknik analisis data untuk respon siswa dilakukan dengan menggunakan skala Likert. Skala ini disusun dalam bentuk suatu pernyataan dan diikuti oleh lima respon yang menunjukkan tingkatan.

SS

$\mathrm{S}$

TB/RR

TS

STS

$$
\begin{aligned}
& =\text { Sangat setuju. } \\
& =\text { Setuju. } \\
& =\text { Tidak berpendapat/ragu-ragu. } \\
& =\text { Tidak Setuju. } \\
& =\text { Sangat tidak setuju. }
\end{aligned}
$$

Penskoran skala likert dapat dimulai dari sangat negatif sampai dengan sangat positif, sebagai berikut: Untuk pernyataan positif (favorable), $\mathrm{SS}=5, \mathrm{~S}=4$, $\mathrm{RR}=3, \mathrm{TS}=2$, dan $\mathrm{STS}=1$; atau $\mathrm{SS}=4, \mathrm{~S}=3, \mathrm{RR}=$ $2, \mathrm{TS}=1$, dan STS $=0$.

Ratumanan dan Laurens (2011)

Data respon siswa dianalisis menggunakan rumus:

$$
P=\frac{\sum K}{\sum N}
$$

Keterangan:

$$
\begin{array}{ll}
P & =\text { Presentase respon siswa } \\
\sum K & =\text { Jumlah skor respon siswa } \\
\sum N & =\text { Jumlah seluruh skor respon siswa }
\end{array}
$$

Kriteria deskripsi pada tabel 5, berikut.

Tabel 5. Kriteria Respon Siswa

\begin{tabular}{|c|c|}
\hline Nilai $(\%)$ & Kriteria \\
\hline $85 \% \geq$ Respon Siswa & Sangat positif (SP) \\
\hline $70 \% \geq$ Respon Siswa $<85 \%$ & Positif $(\mathrm{P})$ \\
\hline $50 \% \geq$ Respon Siswa $<70 \%$ & Kurang Positif $(\mathrm{KP})$ \\
\hline Respon Siswa $<50 \%$ & Tidak Positif $(\mathrm{TP})$ \\
\hline
\end{tabular}

Temuan Kendala atau hambatan-hambatan di dalam pembelajaran dianalisis secara deskriptif kualitatif yaitu pengamat dan peneliti memberikan catatan tentang hambatan atau kendala yang terjadi pada saat pelaksanaan pembelajaran 


\section{HASIL ANALISIS DAN DISKUSI}

Penelitian pengembangan perangkat pembelajaran dengan model inkuiri terbimbing berbantuan videoscribe ini dilaksanakan dengan dua tahap. Pertama, tahap pengembangan perangkat pembelajaran. Kedua, tahap implemetasi perangkat pembelajaran. Tahap pengembangan perangkat pembelajaran meliputi Rencana Pelaksanaan Pembelajaran (RPP), Lembar Kegiatan Siswa (LKS), Buku Ajar Siswa (BAS), media videoscribe, dan Tes Hasil Belajar (THB). Perangkat pembelajaran yang telah dikembangkan kemudian ditelaah atau divalidasi oleh ahli. Hasil validasi ahli menentukan kelayakan perangkat pembelajaran untuk diterapkan atau perlu direvisi, sebelum digunakan dalam proses pembelajaran. Perangkat pembelajaran dapat diimplementasikan jika telah melalui proses validasi dan memperoleh hasil minimal baik.

Tahap kedua yakni, tahap implementasi perangkat pembelajaran. Pada tahap uji coba II, implementasi perangkat pembelajaran dilakukan pada 120 orang siswa kelas X MIA di SMA Negeri 1 Kedungwaru, Tulungagung, Jawa Timur, Tahun pembelajaran 2014/2015. Pada implementasi ini, data yang diperoleh yakni keterlaksanaan perangkat pembelajaran, data hasil belajar siswa, respons siswa, dan hambatanhambatan yang muncul selama proses implementasi berlangsung. Berikut ini uraian hasil validasi pengembangan perangkat pembelajaran dan data yang diperoleh selama penelitian.

\section{A. Hasil Validasi Perangkat Pembelajaran}

Berdasarkan hasil validasi dari tiga ahli untuk: (1) Rencana Pelaksanaan Pembelajaran (RPP) mendapat skor rata-rata keseluruhan adalah 3.53 menurut Ratumanan dan Laurens (2006) hasil validasi dengan interval skor 2,6 $\leq \mathrm{SV}<3,5$ berkategori baik. Hasil tersebut menunjukkan Rencana Pelaksanaan Pembelajaran (RPP) yang telah dikembangkan dapat diimplementasikan dalam pembelajaran setelah direvisi berdasarkan saran dari ahli; (2) LKS mendapat skor rata-rata adalah 3.66 menurut Ratumanan dan Laurens (2006) hasil validasi dengan interval skor 3,6 $\leq \mathrm{P}<4$ berkategori sangat baik. Hasil tersebut menunjukkan Lembar Kegiatan Siswa (LKS) yang telah dikembangkan dapat diimplementasikan dalam pembelajaran setelah direvisi berdasarkan saran dari ahli; (3) Buku Ajar Siswa BAS) skor rata-rata adalah 3.42 menurut Ratumanan dan Laurens (2006) hasil validasi dengan interval skor $2,6 \leq \mathrm{SV}<3,5$ berkategori baik, Hasil tersebut menunjukkan Rencana Pelaksanaan Pembelajaran (RPP) yang telah dikembangkan dapat diimplementasikan dalam pembelajaran setelah direvisi berdasarkan saran dari ahli; (4) Media pembelajaran (VideoScribe) mendapat skor rata-rata adalah 3.37 menurut Ratumanan dan Laurens (2006) hasil validasi dengan interval skor $2,6 \leq \mathrm{SV}<3,5$ berkategori baik,
Hasil tersebut menunjukkan Rencana Pelaksanaan Pembelajaran (RPP) yang telah dikembangkan dapat diimplementasikan dalam pembelajaran setelah direvisi berdasarkan saran dari ahli; (5) instrumen hasil belajar: (a) soal tes pengetahuan dan ketererampilan berpikir kritis mendapat skor rata-rata 3.31 menurut Ratumanan dan Laurens (2006) hasil validasi dengan interval skor $2,6 \leq \mathrm{SV}<3,5$ berkategori baik dan dapat digunakan dengan sedikit revisi; (b) soal tes formatif mendapat skor rata-rata keseluruhan hasil validasi adalah 3.18, menurut Ratumanan dan Laurens (2006) hasil validasi dengan interval skor 2,6 $\leq \mathrm{SV}<3,5$ berkategori baik dan dapat digunakan dengan sedikit revisi. Hasil tersebut menunjukkan Rencana Pelaksanaan Pembelajaran (RPP) yang telah dikembangkan dapat diimplementasikan dalam pembelajaran setelah direvisi berdasarkan saran dari ahli.

\section{B. Implementasi Perangkat Pembelajaran}

Perangkat pembelajaran yang telah melalui proses telaah atau validasi oleh ahli, direvisi, dan mendapatkan hasil minimal berkategori baik, maka perangkat tersebut selanjutnya dapat diimplementasikan dalam pembelajaran. Pada implementasi perangkat pembelajaran diamati oleh dua orang pengamat. Hasil pengamatan berupa persentase keterlaksanaan perangkat pembelajaran, hasil belajar, dan hambatanhambatan yang muncul selama proses pembelajaran. Berikut ini hasil implementasi perangkat pembelajaran.

Rata-rata keterlaksaan RPP memperoleh skor keseluruhan tiga kelas yakni 3.67 dengan kategori baik, dengan keterlaksaan $92 \%$. Berikut ini data tersaji dalam gambar 1 .

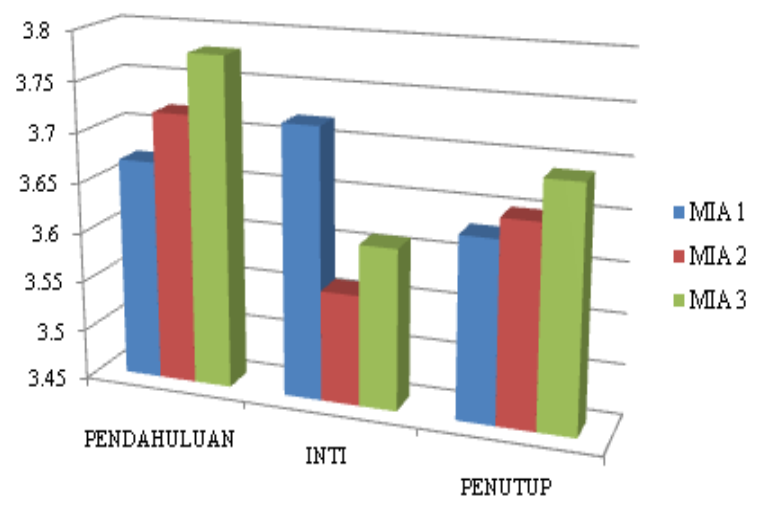

Gambar 1. Diagram Keterlaksanaan RPP

Kegiatan pendahuluan meliputi: memulai kegiatan pembelajaran dengan berdo'a; melakukan apersepsi; memotivasi siswa dengan menayangkan videoscribe; menyajikan permasalahan; menyampaiakn tujuan pembelajaran, dan membagi lembar kegiatan siswa dalam beberapa kelompok. Kegiatan inti meliputi: membimbing siswa merumuskan hipotesis, membimbing siswa menentukan variabel manipulasi, variabel respon, dan variabel kontrol, membimbing 
siswa mempersiapkan dan melakukan eksperimen, membimbing siswa menganalisis data hasil eksperimen, membimbing siswa merumuskan kesimpulan. Sedangkan kegiatan penutup meliputi: membimbing siswa mengevaluasi, membuat kesimpulan akhir, dan memberikan tes formatif.

Hasil pengamatan keterlaksanaan RPP mendapat hambatan pada alokasi waktu pembelajaran yang kurang tepat. Hal ini terjadi pada fase melakukan eksperimen, siswa belum efektif dan efisien dalam melaksanakan eksperimen, perlu bimbingan dan kontrol yang lebih selama pelaksanaan eksperimen. Hal ini diperbaiki pada pertemuan berikutnya. Pada pertemuan berikutnya Siswa sudah mulai terbiasa dengan kegiatan eksperimen, analisis eksperimen yang berkaitan dengan keterampilan berpikir kritis. Peran guru sudah mulai dikurangi sedikit demi sedikit siswa lebih aktif dalam kegiatan eksperimen, dan melakukan diskusi dengan teman sebaya, terkait pengambilan data dan analisis. Hal ini sesuai dengan teori Vygotsky tentang konsep zona of proximal development dan scaffolding. Pada konsep zone of proximal development, menjelaskan bahwa siswa tidak dapat mengerjakan tugas sendiri tetapi dapat menyelesaikannya bila dibantu oleh teman sebaya mereka atau orang yang lebih dewasa (dalam Nur, 2008). Pada teori pembelajaran sosial Vygotsky (dalam Nur, 2008) menekankan pada konsep scaffoliding yang berarti memberikan bantuan tahap demi tahap pada siswa untuk belajar dan memecahkan masalah, kemudian mengurangi bantuan dan memberikan kesempatan siswa untuk mengambil alih tanggung jawab setelah siswa dapat melakukannya.

\section{Hasil Belajar}

\section{Kompetensi Sikap}

Kompetensi sikap meliputi sikap spiritual, dan sikap sosial. Penilaian kompetensi sikap didasarkan pada Lampiran Permendikbud RI No. 104 Tahun 2014. Instrument yang digunakan yakni lembar observasi dengan rubrik. Pada penelitian ini, penilaian kompetensi sikap dilakukan dengan observasi (pengamtan) oleh dua orang pengamat menggunakan lembar observasi sikap. Indikator sikap spiritual pada penelitian ini yakni, siswa dapat memberikan contoh peristiwa yang teratur dan kompleks dimana manusia tidak dapat menciptakan kecuali Tuhan. Aspek sikap sosial yang diamati meliputi jujur, tanggung jawab, peduli lingkungan, dan disiplin. Berdasarkan data hasil belajar kompetensi sikap rerata penilaian > 3 menunjukkan bahwan sikap spiritual dan sikap sosial sering muncul dalam pembelajaran. Hal ini menunjukkan sikap spiritual dan sikap sosial yang diamati dalam pembelajaran dapat dikembangkan.

Hasil pengamatan pada aspek sikap ini menunjukkan bahwa pembelajaran menggunakan model inkuiri pada kegiatan eksperimen dapat memunculkan sikap sosial yakni jujur, siswa mencatat data dan merumuskan kesimpulan sesuai dengan data hasil pengamatan eksperimen, tidak mencontek jawaban orang lain; sikap tanggung jawab, siswa mengembalikan alat alat eksperimen dan membuat laporan hasil eksperimen; sikap peduli lingkungan; dan displin. Hal ini senada dengan apa yang disampaiakan oleh Kuhlthau dan Klentschy yang menyatakan bahwa inkuiri terbimbing dirancanag untuk membimbing siswa dalam proses berpikir, membangun pengetahuan, meningkatkan minta untuk mencari informasi dan penyelidikan untuk mendapatkan pengetahuan dan pemahaman mendalam, bertahap pada belajar mandiri.

\section{Aspek Pengetahuan}

Tes hasil belajar pada aspek pengetahuan diberikan setelah pembelajaran pada setiap pertemuan (tes formatif), sebelum pembelajaran (pretest), setelah pembelajaran (posttest). Berdasarkan data hasil belajar, hasil tes sebelum pembelajaran (pretest) seluruh siswa tidak mencapai ketuntasan. Belum tercapainya ketuntasan siswa secara individu maupun secara klasikal dikarenakan siswa kurang memahami betul konsep materi kalor. Sebagian besar siswa kurang paham tentang kalor sebagai sebuah energi bukan panas.

Berdasarkan teori Bruner, pembelajaran dengan penemuan melatihkan keterampilan kognitif, memecahkan masalah, membangkitkan keingin tahuan siswa, memotivasi untuk menlakukan penyelidikan, menganalisisi informasi, dan pengetahuan yang diperoleh bertahan lebih lama. Pembelajaran penemuan ini dapat dilakukan dengan model inkuiri terbimbing. Pembelajaran berpusat pada siswa, siswa aktif menemukan sediri. Guru berperan sebagai pembimbing selama proses penemuan. Sesuai dengan teori ini, pemahaman siswa mengalami kemuajuan, terlihat dari $\mathrm{N}$-gain yang menunjukkan peningkatan dengan kategori tinggi. Pada kelas X1 MIA, rata-rata N-gain sebesar 0.70 berkategori tinggi; kelas X2 MIA, rata-rata N-gain 0.73 berkategori tinggi; dan kelas X3 MIA, rata-rata Ngain 0.72 berkategori tinggi.

\section{Keterampilan Berpikir Kritis}

Pengembangan perangkat pembelajaran model inkuiri terbimbing pada penelitian ini berorientasi pada keterampilan berpikir kritis. Keterampilan berpikir kritis yang diukur pada penelitian ini adalah merumuskan jawaban sementara dari suatu permasalahan (memberikan argumen), membuat hipotesisi, menentukan variabel-variabel eksperimen, merancang eksperimen, melakukan eksperimen, membuat tabel, grafik, menganalisis, mengevaluasi, dan membuat keismpulan dari permasalahan.

Keterampilan berpikir kritis diukur menggunakan tes keterampilan berpikir kritis yang diberikan sebelum 
pembelajaran (pretets), dan setelah pembelajaran (posttest). Peningkatan keterampilan berpikir kritis dianalisis menggunakan $N$-gain berdasarkan hasil pretest dan postets. Data hasil belajar keterampilan berpikir kritis semua siswa pada pretest tidak mencapai ketuntasan belajar minimal. Hal ini dikarenakan siswa belum terbiasa dilatihkan keterampilan berpikir kritis. Proses pembelajaran penemuan meningkatkan kemampuan penalaran siswa. Pada pembelajaran inkuiri terbimbing diperlukan berpikir kritis, logis, dan mempertimbangkan solusi alternatif dalam penyelidikan. Inkuiri terbimbing melatihkan siswa secara bertahap untuk mandiri dalam melakukan penyelidikan. Mendukung pembelajaran inkuiri terbimbing dapat menggunakan teknik yang dikembangkan Ausubel yakni advance organizer, membantu siswa memahami materi baru dengan mengingat kembali informasi-informasi yang berkaitan. Tetapi metode pengaktifan ini dapat gagal jika pengetahuan sebelumnya lemah (Alverman et al, 1985). Hal ini dapat jembatani dengan menggunakan media video scribe. Video Scribe dapat mengilustrasikan konsep yang kompleks dalam pembelajaran, meningkatkan minat, dan motivasi siswa (Sparkol, 2014).

Keterampilan berpikir kritis mengalami peningkatan dengan kategori tinggi. Hal ini merujuk pada nilai Ngain siswa di tiga kelas. $\mathrm{N}$-gain keterampilan berpikir kritis kelas X1 MIA sebesar 0.75, berkategori tinggi; . $\mathrm{N}$-gain keterampilan berpikir kritis kelas X2 MIA sebesar 0.80, berkategori tinggi; dan . N-gain keterampilan berpikir kritis kelas X3 MIA sebesar 0.76 berkategori tinggi. Sesuai dengan hasil penelitian Kuhlthau yang menyatakan bahwa pembelajaran inkuiri terbimbing dapat mengembangkan kemampuan berpikir tingkat tinggi melalui berpikir kritis selama proses pembelajaran.. Hal ini didukung oleh hasil penelitian Liliasari (2010) yang menyimpulkan bahwa pembelajaran inkuiri menggunakan tekonologi informasi dan komunikasi dapat mengkatifkan siswa, mendukung teori dan praktikum di laboratorium, memotivasi, dan meningkatkan penguasaan konsep siswa.

Peningkatan keterampilan berpikir kritis siswa diperkuat dengan hasil analisis ketuntasan tiap indikator berpikir kritis. Pada pretest tidak ada indikator berpikir kritis yang mencapai ketuntasan. Setelah pembelajaran dengan model inkuiri terbimbing berbantuan videoscribe hasil posttest pada ketercapaian ketuntasan indikator berpikir kritis yakni lebih dari $75 \%$ siswa mencapai ketuntasan.

\section{Keterampilan}

Penilaian aspek keterampilan dengan observasi, menggunakan skala penilaian. Kompetensi keterampilan yang diukur pada penelitian ini meliputi: menyiapkan set alat eksperimen, merangkai alat eksperimen, menggunakan termometer, membaca suhu yang terukur pada termometer, mengisikan data pada tabel pengamatan, membuat grafik hasil pengamatan, dan merapikan set alat eksperimen. Pengukuran kompetensi keterampilan pada penelitian ini dilakukan dengan pengamatan oleh dua orang pengamatan menggunakan lembar observasi keterampilan, dan laporan hasil eksperimen individu siswa.

Berdasarkan hasil penilaian kompetensi keterampilan X1 MIA, X2 MIA, dan X3 MIA mendapat rata-rata $\geq 75 \%$ dengan predikat minimal $\mathrm{B}$. Hasil ini menunjukkan bahwa pembelajaran dengan menggunakan model inkuiri terbimbng dapat menjadi sarana guru untuk dapat menyesuaikan pengalaman belajar, sumber daya, kebutuhan yang disesuaikan dengan kemampuan masing-masing siswa. Pembelajaran penemuan melibatkan siswa dalam proses menjawab pertanyaan tentang fenomena alam atau peristiwa dengan melakukan penyelidikan ilmiah dimana mereka bekerja sama mengembangkan rencanan, mengumpulkan dan menjelaskan bukti, menghubungkan penjelasan pengetahuan ilmiah, dan berkomunikasi untuk meningkatkan pemahaman.

\section{E. Sensitivitas Butir Soal}

Efek pembalajaran dapat diketahui dengan menganalisis tingkat sensitivitas butir soal (Gronlund,1977). Sensitivitas butir soal diukur dengan jumlah siswa yang menjawab benar pada pretest dan posttest. Pada penelitian ini analisis sensitivitas butir soal dilakukan pada soal tes keterampilan berpikir kritis. Terdiri dari 6 soal pilihan ganda, dan 3 soal uraian. Hasil analisi sensitivitas butir soal menunjukkan indeks sensitivitas sebesar 0.48 untuk soal pilihan ganda, dan 0.50 untuk soal uraian. Menurut Crocker \& Algina (1986, dalam Lauren \& Ratumanan, 2011) indeks sensitivitas butir pada dasarnya merupakan ukuran seberapa baik butir tersebut membedakan antara peserta didik yang telah dan yang belum mengikuti pembelajaran. Indeks sensitivitas butir yang efektif berada diantara $0.00-1.00$. Semakin besar indeks sensitivitas butir menunjukkan semakin besar keberhasilan pembelajaran (Lauren \& Ratumanan, 2011). Maka, dapat ditarik kesimpulan bahwa butir soal pada penelitian ini memberikan efek keberhasilan pada pembelajaran.

\section{F. Respons Siswa}

Data respon siswa digunakan untuk mengevaluasi perangkat pembelajaran yang telah dikembangkan, dan kegiatan proses pembelajaran untuk perbaikan. Data respon siswa menunjukkan bahwa siswa senang, dan memberikan respon positif lebih dari $87 \%$ terhadap 
pembelajaran menggunakan model inkuiri terbimbing menggunakan eksperimen, siswa senang karena dapat langsung mengaplikasikan pelajaran. Lebih dari $85 \%$ siswa memberikan respon positif terhadap pembelajaran model inkuiri terbimbing yang membuat siswa lebih berani mengemukakan pendapat, berdiskusi dan lebih paham konsep fisika yang ditemukan mellaui eksperimen. Respon siswa terhadap model inkuiri berbantuan video scribe positif, lebih dari $85 \%$ siswa termotivasi. Lebih dari $82 \%$ siswa memberikan respon positif terhadap model inkuri terbiming dalam melatihkan keterampilan berpikir kritis mereka. Lebih dari $80 \%$ siswa memberikan respon positif terhadap Buku Ajar Siswa (BAS) dan Lembar Kegiatan Siswa (LKS), menarik, mudah dipahami, terdapat hal-hal baru, dan dapat melatihkan keterampilan berpikir kritis, dan $83 \%$ siswa memberikan respon postif terhadap peran guru selama pembelajaran. Berdasarkan data tersebut, dapat disimpulkan bahwa siswa memberikan respon positif terhadap model pembelajaran dan perangkat pembelajaran yang telah dikembangkan.

\section{G. Hambatan-hambatan}

Hambatan-hambatan yang muncul menjadi salah satu faktor yang mempengaruhi keberhasilan dari tujuan kegiatan pembelajaran. Hambatan-hambatan yang muncul meliputi alokasi waktu yang relatif banyak pada fase eksperimen, ketersediaan peralatan eksperimen, pengawasan yang lebih terhadap siswa selama proses kegiatan eksperimen, dan ketepatan penilaian secara individu aspek kompetensi sikap dan keterampilan yang tercermin pada laporan eksperimen.

Hambatan-hambatan yang muncul semalam penelitian didisusikan dengan guru dan observer, didapatkan sebuah soluasi yakni sebelum kegiatan pembelajaran, peralatan yang akan digunakan untuk ekperimen disiapkan dan diuji cobakan terlebih dahulu. Siswa diberi pengarahan dan pengawasan yang lebih sebelum melaksanakan kegiatan eksperimen. Membuat laporan individu dari kegiatan eksperimen yang pengambilan datanya dilakukan secara berkelompok, hal ini bertujuan untuk penilaian siswa secara individu lebih akurat. Pada akhir setiap pertemuan selain diberikan tes formatif untuk mengecek pemahaman pada materi yang telah diajarkan, siswa diberikan arahan untuk mempersiapkan eksperimen pada pertemuan berikutnya, yang bertujuan agar siswa telah memiliki pengetahuan awal yang cukup dan kegiatan eksperimen lebih efektif dan efisien.

\section{KESIMPULAN}

\section{A. Simpulan}

Berdasarkan hasil temuan penelitian, dapat disimpulkan bahwa perangkat pembelajaran model inkuiri terbimbing berbantuan videoscribe pada materi kalor yang dikembangkan peneliti layak digunakan untuk meningkatkan hasil belajar siswa SMA.

\section{B. Saran}

1. Pembelajaran di sekolah sebaiknya lebih berorientasi pada pendekatan ilmiah dengan melatihkan keterampilan berpikir kritis siswa, misalnya menggunakan model inkuiri terbimbing.

2. Mempersiapkan alat, alokasi waktu yang baik agar proses eksperimen berjalan dengan baik.

3. Laporan eksperimen sebaiknya individu, lebih mudah untuk penilaian masing-masing individu

\section{DAFTAR PUSTAKA}

Arifin, Z. (2009). Evaluasi Pembelajaran. Bandung: PT Remaja Rosda Karya

Bektiarso, S. (2000). Pentingnya Konsepi Awal dalam Pembelajaran Fisika. Jurnal Saintifika, Vol.1 No.1 pp. $11-20$.

Costa, A.L. (Ed.). (1985). Developing Minds, a ResourceBook for Teaching and Thinking. Association Supervision and Curriculum, USA

Ennis, R. (1985). The Critical Thinking Skills. Boston: Allyn \& Bacon

Hake. (1999). Analyzing Change/Gain Scores. (Online). Tersedia http://www.physicsindiana.edu/sdi/AnalyzingChange-Gain.pd. Diakses 17 Desember 2014

Kemendikbud. (2013). Permendikbud No. 64 Tahun 2013 tentang Standar Isi. Jakarta: Kemendikbud

Khulthau, C.C., \& R.J, Todd. (2008). Guided Inquiry. (Online). Tersedia. www. icwc.wikispaces.com/file/view/Guided+Inquiry. doc. Diakses 13 Desember 2012

Liliasari., Iriany., dan Setiabudi, A. (2010). Model Pembelajaran Inkuiri Laboratorium Berbasis Teknologi Informasi pada Konsep Laju Reaksi untuk Meningkatkan Keterampilan Generik Sains dan Keterampilan Berpikir Kreatif Siswa $S M U$. Bandung : Sekolah Pascasarjana UPI

Mayer, R. (2009). Multi-Media Learning $2^{\text {nd }}$ Editio). Cambridge: University Press

Miri, B., David, B., and Uri, Z. (2007). Purposely Teaching for the Promotion of Highher-order Thingking Skills: A Case of Critical Thingking. Research Science Education. Vol 37 pp.353 369

Novak, J.D. \& D.B. Gowin, (1985). Learning How to Learn. New York: Cambridge University Press.

Rahmawati, Widodo, W., dan Prabowo. (2013). Pengembangan Perangkat Pembelajaran dengan Metode Pembelajaran Penemuan Terbimbing 
(Guided Discovery Learning) untuk Melatih Keterampilan Berpikir Kritis dan Penguasaan Konsep pada Siswa SMP. Jurnal Penelitian Pendidikan Sains. Vol.1 No.2 pp.80 - 85.

Ratumanan, G.T., dan T, Laurens. 2006. Evaluasi Hasil yang Relevan dengan Memecahkan Problematika Belajar dan Mengajar. Bandung:CV Alfabeta

Ratumanan, TG dan Laurens, T. (2011). Evaluasi hasil belajar yang relevan dengan kurikulum berbasis kompetensi. Surabaya: Unesa University Press.

Sparkol. (2014). VideoScribe for Education. (Online). Tersedia www.videoscribe.co/education-apply. Diakses pada tanggal 2 Februari 2015.

Sutarto \& Indrawati. (2010). Media Pembelajaran Fisika. Jember: Universitas Jember.
Thohrir, M., Sugimin, dan Wasis. (2013). Peningkatan Keterampilan Berpikir Kritis Melalui Pembelajaran Metode Penemuan Terbimbing dalam Upaya Remediasi Miskonsepsi Materi Listrik Dinamis. Jurnal Penelitian Pendidikan Sains. Vol.1 No.2 pp.74 - 79.

Windarti., Tjandrakirana., dan Widodo. (2014). Melatihkan Keterampilan Berpikir Kritisi Menggunakan Metode Pembelajaran Penemuan Terbimbing (Guided Discovery) Pada Siswa SMP. Jurnal Penelitian Pendidikan Sains. Vol.2 No.2 pp.87 - 94.

Zero, D. (2011). Thinking Critiically and Resolving Misconceptions. (Online). Tersedia. https//sities.google.com/site/dmzeroproject/H ome/critical-thinking-and-misconceptions. Diakses pada tanggal 26 Maret 2015. 